\title{
Simultaneous Determination of Lactulose and Lactose in Conserved Milk by HPLC-RID
}

\author{
Michelle Fernandes Silveira, ${ }^{1}$ Lourdes Maria Pessôa Masson, ${ }^{1}$ \\ José Francisco Pereira Martins, ${ }^{2}$ Thiago da Silveira Álvares, ${ }^{3}$ \\ Vânia Margaret Flosi Paschoalin, ${ }^{3}$ César Lázaro de la Torre, ${ }^{4,5}$ \\ and Carlos Adam Conte-Junior ${ }^{3,5}$ \\ ${ }^{1}$ Federal Institute of Rio de Janeiro, No. 88, Pereira de Almeida Street, 20260-100 Praça da Bandeira, RJ, Brazil \\ ${ }^{2}$ Department of Food Technology, Federal Rural University of Rio de Janeiro, 23890-000 Seropédica, RJ, Brazil \\ ${ }^{3}$ Institute of Nutrition, Federal University of Rio de Janeiro, Macaé Campus, Imburo Road, Ajuda, 27979-000 Macaé, RJ, Brazil \\ ${ }^{4}$ Laboratory of Pharmacology and Toxicology, Faculty of Veterinary Medicine, Major National University of San Marcos, \\ Circunvalación Avenue, San Borja, Lima 41, Peru \\ ${ }^{5}$ Department of Food Technology, Fluminense Federal University, No. 64, 24230-340 Niteroi, RJ, Brazil
}

Correspondence should be addressed to Carlos Adam Conte-Junior; carlosconte@id.uff.br

Received 31 July 2015; Accepted 10 September 2015

Academic Editor: Miguel de la Guardia

Copyright (c) 2015 Michelle Fernandes Silveira et al. This is an open access article distributed under the Creative Commons Attribution License, which permits unrestricted use, distribution, and reproduction in any medium, provided the original work is properly cited.

Heat treatment is applied to dairy products to ensure microbiological quality and increase the shelf life. However, a suitable control of this process is necessary to guarantee nutritional and sensory quality. The aim of this study is to adapt the high performance liquid chromatography (HPLC) method for determination of lactulose and lactose content in commercial samples of UHT and sweetened condensed milk. The HPLC method used showed a good resolution of the analytes evaluated. The analyzed UHT milk samples presented levels for lactulose in accordance with the limit recommended by the International Dairy Federation. There was no significant variation in lactulose concentration for sweetened condensed milk samples. However, one sweetened condensed milk sample showed lactose level lower than the established values (10-12\%).

This paper is dedicated to the memory of Professor Joab Trajano Silva, Ph.D.

\section{Introduction}

According to Brazilian legislation, milk is a product obtained from full and uninterrupted milking, in conditions of hygienic, healthy, well-fed, and rested cows [1]. It is a highly nutritious food to ensure the supply of essential nutrients, especially for children. Since the most remote times, dairy animals have been domesticated for this purpose [2]. According to national and international organizations, Brazil is the fourth largest milk producer in the world, with production of 32,091 billion liters in 2011, staying behind only the United States, India, and China $[3,4]$.
One of the challenges of the milk industry is the conservation. Nowadays many technologies to achieve this purpose exist. However, the ultrahigh temperature (UHT) treatment is applied in most dairy products to guarantee their microbiological safety and increase the shelf life [5]. Another method commonly used is the concentration; in this method, the milk is preserved with a considerable reduction of water content by evaporation. If a large quantity of sucrose is added, the product is called sweetened condensed milk $[6,7]$.

A proper control of the thermal process in both methods is important to ensure their nutritional and sensory quality since their effect on milk constituents is fundamental in 


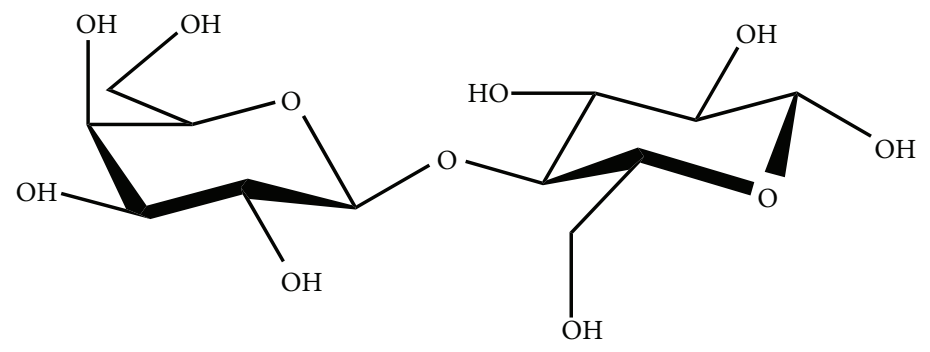

Lactose

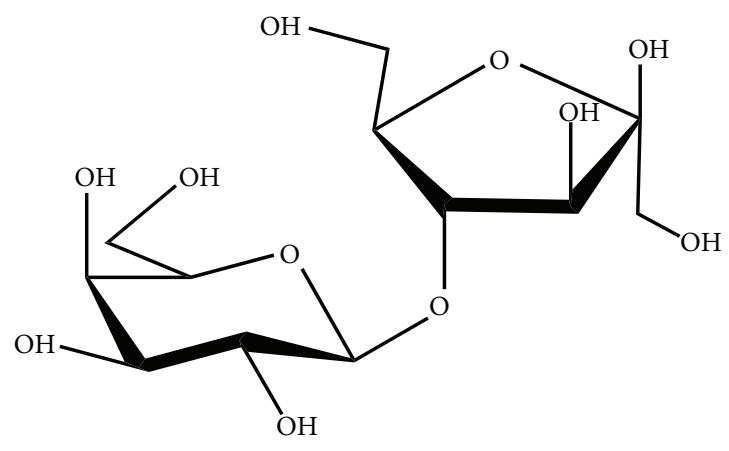

Lactulose

FIGURE 1: Basic structure of lactose and lactulose.

the characterization of the final product $[8,9]$. The severity of thermal treatment can lead to degradation of milk constituents like proteins, enzymes, and vitamins; some of these substances could be indicators to assess the thermal damage in milk $[8,10]$.

Among the carbohydrates, lactose, originating from the blood glucose in the mammary gland, is one of the main constituents of milk [11]. However, when lactose is subjected to moderate heating, its isomerization can occur with the lactulose formation (glucose/fructose) via Lobry de BruynAlberda van Ekenstein reaction, through the intermediate compound 1,2-enediol [12-14]. Consequently, the quantity of lactulose is directly proportional to the intensity of the heat treatment applied [15] and could be useful such as indicators of the quality of milk processing [8]. Lactose and lactulose chemical structures are shown in Figure 1. According to the International Dairy Federation (IDF), UHT milk contains less than $0.06 \mathrm{~g} / \mathrm{mL}$ of lactulose, while the hydrostatically sterilized milk presents level of lactulose higher than this value [16]. A precise analysis of lactose and lactulose in food is interesting because both substances exert dose-dependent effects upon intake (lactose maldigestion and prebiotic or laxative action of lactulose) [17].

Early methods of lactose analyses such as polarimetric, gravimetric, Lane-Eynon, and Chloramine-T methods are no more useful because all of them assumed that lactose is the only carbohydrate present in milk and this is a problem in dairy products (fermented milk, cheese, etc.) with appreciable amounts of monosaccharides [18]. More recently, infrared spectroscopic [19], chromatography [20, 21], enzymatic colorimetric [22-24], and capillary electrophoresis [25] have been used for the detection and quantification of lactose and lactulose. From these, high performance liquid chromatography (HPLC) is a very promising technique and considerable research was carried out on the quantitative determination of lactulose [26]. Over all detectors coupled to HPLC, the refractive index detector (RID) is the most widely used for sugars because no fluorophore (fluorescence detector) or chromophore (UV detector) is necessary; in other words, no derivatization is required. RID operates under the principle that the refractive index changes depending upon the refracting or light bending properties of liquids [27]. The aim of this paper was the development of a modified HPLC-RID method for simultaneous determination and quantification of lactulose and lactose in commercial UHT and sweetened condensed milk.

\section{Materials and Methods}

2.1. Sample Collection. Commercial brands of skimmed UHT milk (UHT) $(n=5)$ and sweetened condensed milk (COND) $(n=5)$ were obtained in markets located in the city of Rio de Janeiro, Brazil. Samples were transported to the laboratory in insulated polystyrene boxes on ice during $1 \mathrm{~h}$.

2.2. Chemicals and Reagents. The standard of lactose and lactulose (both with $98 \%$ of purity) was purchased from SigmaAldrich (Sao Paulo, Brazil). The HPLC grade reagents used were acetonitrile (Tedia, RJ, Brazil) and all other reagents like methanol (Tedia, RJ, Brazil), zinc sulphate solution (Carrez I), and potassium hexacyanoferrate solution (Carrez II) were of analytical grade. Ultrapure water was obtained from Simplicity System (Millipore, Molsheim, France).

2.3. Standard Preparation and Calibration Curve. Linearity of UHT milk was performed injected six lactose (range of 0.625 to $20 \mathrm{mg} / \mathrm{mL}$ ) and six lactulose standards (range from 0.0625 to $1 \mathrm{mg} / \mathrm{mL}$ ). On the other hand, the linearity of sweetened condensed milk was performed with six levels of lactulose standard (range of 1 to $100 \mathrm{mg} / \mathrm{mL}$ ) and the same range for lactose. The standard solutions were dissolved in ethanol: water $(1: 1)$ and filtered on PTFE membrane with pore size of $0.45 \mu \mathrm{m}$ and $\varnothing=13 \mathrm{~mm}$ (Millipore, USA). Solutions were kept at $4^{\circ} \mathrm{C}$ until the injection in the chromatography system.

2.4. Milk Sample Preparation. The methods proposed by Chávez-Servín et al. [28] and Schuster-Wolff-Bühring et al. [17] were adapted for our experiment. In brief, a protein precipitation was achieved with a sequential mixture of $1.5 \mathrm{~mL}$ of the skimmed UHT milk, $30 \mu \mathrm{L}$ Carrez I solution, and the same volume of Carrez II solution. The resulting volume was centrifuged (Hermle Z $360 \mathrm{~K}$, Germany) at $12000 \mathrm{RPM}$ for $4^{\circ} \mathrm{C} / 30 \mathrm{~min}$. Afterwards, the solution was 
filtered in the sterile polyethersulfone membrane with pore size of $0.22 \mu \mathrm{m}$ and $\varnothing=33 \mathrm{~mm}$ (Millipore, USA). Before the chromatograph injection, the extract obtained was diluted in ethanol : water $(1: 1)$. Sweetened condensed milk $(0.60 \mathrm{~g})$ was weighted and diluted with $1.5 \mathrm{~mL}$ of ultrapure water. The solution was stirred in mechanical agitator (Biotech International, Melsungen, Germany), during $30 \mathrm{~min}$. After dilution of the sample, the resulting solution followed the same procedure described for the skimmed UHT milk.

2.5. Chromatographic Conditions. Milk samples and standard solution of lactose and lactulose were analyzed from the HPLC system (Shimadzu) provided by degasser (DGU20A3), binary pump (LC-20AD), automatic injector sample (SIL-20AC), column oven (CTO-20A), and refractive index detector (RID 10A). An isocratic HPLC method involves a mobile phase of acetonitrile: water $(75: 25, \mathrm{v} / \mathrm{v})$, a Prevail Carbohydrate ES precolumn $(5 \mu \mathrm{m}, 7.5 \mathrm{~mm} \times 4.6 \mathrm{~mm})$, and a Prevail Carbohydrate ES column $(5 \mu \mathrm{m}, 250 \mathrm{~mm} \times 4.6 \mathrm{~mm})$. The system used a flow of $1.1 \mathrm{~mL} / \mathrm{min}$, an oven temperature of $30^{\circ} \mathrm{C}$, an injection volume of $20 \mu \mathrm{L}$, and a running time of $20 \mathrm{~min}$. Lactose and lactulose were identified by retention time and were quantified by peak area.

2.6. Experimental Design and Statistical Analyses. Data collected in this study were analyzed using GraphPad Prism 5.00 package [29] for Windows by one-way ANOVA, and the means were compared with Tukey's test $(P<0.05)$.

\section{Results and Discussion}

3.1. Validation Parameters. A linearity of the chromatography method was verified with the coefficient of determination $\left(R^{2}\right)$. According to the results, values of $R^{2}$ for lactose and lactulose (UHT and sweetened condensed milk) were superior to 0.99 (Figure 2). These results were possible due to the use of six different levels for the construction of the calibration curve, which showed a best-fit linear regression model. The legislation of the European Community recommends at least five concentration levels for the construction of calibration curves [30]. Our results are consistent with Brazilian legislation. Health Surveillance Agency (ANVISA) and National Institute of Metrology, Quality and Technology (INMETRO) consider 0.99 and 0.90 excellent $R^{2}$ values, respectively [31, 32].

A separation performance of lactose and lactulose is represented in Figure 3. A standard of (I) lactulose and (II) lactose showed a retention time of 13.6 and $17.2 \mathrm{~min}$, respectively. The same retention time was observed in milk samples. This retention time was similar to that reported by Corzo et al. [18] who used similar chromatography conditions to ours except for flow rate $(0.9 \mathrm{~mL} / \mathrm{min})$. These authors remarked the advantage of Prevail column in terms of clear peak resolution and short time analysis for lactose and lactulose. Our result showed that a highest content of lactose in UHT milk and of lactulose in condensed milk has been verified. Food samples may contain components that interfere with performance measurement and may increase or decrease the signal detector [33]. It is important to remark
TABLE 1: Concentrations of lactose and lactulose found in five different commercial brands of UHT milk.

\begin{tabular}{lcc}
\hline Brand codification & $\begin{array}{c}\text { Concentration in UHT milk }(\mathrm{g} / 100 \mathrm{~mL}) \\
\text { Lactose }\end{array}$ \\
\hline $\mathrm{UHT}_{1}$ & $5.66 \pm 0.01^{\mathrm{a}}$ & $0.04 \pm 0.00^{\mathrm{a}}$ \\
$\mathrm{UHT}_{2}$ & $5.50 \pm 0.51^{\mathrm{a}}$ & $0.02 \pm 0.00^{\mathrm{b}}$ \\
$\mathrm{UHT}_{3}$ & $6.64 \pm 0.35^{\mathrm{a}}$ & $0.05 \pm 0.00^{\mathrm{c}}$ \\
$\mathrm{UHT}_{4}$ & $5.57 \pm 0.21^{\mathrm{a}}$ & $0.02 \pm 0.00^{\mathrm{b}}$ \\
$\mathrm{UHT}_{5}$ & $5.47 \pm 0.11^{\mathrm{a}}$ & $0.06 \pm 0.00^{\mathrm{c}}$ \\
\hline
\end{tabular}

$\mathrm{UHT}_{n}$ : ultrahigh temperature milk brand.

Values with the same letter in the column indicate that there is no statistically significant difference between the samples to the level of $5 \%$.

Values represent the mean \pm SEM.

that HPLC method coupled to refractive index detector (RID) is preferred when lactose and lactulose are determinate simultaneously $[14,26]$. The HPLC is one of the most extensively used techniques employed for the separation of a large variety of carbohydrates in foods [18], as it is particularly advantageous in terms of speed, simplicity of sample preparation (without a prior derivatization), and obtaining a high-resolved chromatogram in a short period of time $(20 \mathrm{~min})$.

3.2. Commercial Milks. The results obtained for quantification of lactose and lactulose in UHT milk are shown in Table 1 . Brands did not present a significant difference $(P>$ 0.05 ) for lactose values varied from 5.47 to $6.64 \mathrm{~g} / 100 \mathrm{~mL}$. Our results are similar to those reported by Walstra et al. [34]; milk presents the levels of 3.8 to $5.3 \mathrm{~g} / 100 \mathrm{~mL}$ of lactose and these values may vary with environmental and biological conditions. On the other hand, concentrations of lactulose showed a significant difference among brands $(P<0.05)$ with values ranging from 0.02 to $0.06 \mathrm{~g} / 100 \mathrm{~mL}$.

When milk is heated, lactose may isomerize into lactulose. According to the IDF and the European Union (EU), the quantification of lactulose allows distinguishing the milk submitted to different thermal processes and can be used as an indicator of the intensity of the heat treatment $[28,35,36]$. Walstra et al. [34] recommend that UHT milk must contain less than $0.06 \mathrm{~g} / 100 \mathrm{~mL}$ of lactulose but these values can vary according to the thermal process. The UHT milk obtained by direct system (injection and infusion) is heated by direct contact with the steam, keeping the high temperature for a short period of time, causing less damage to the product (lactulose values range of 0.005 to $0.011 \mathrm{~g} / 100 \mathrm{~mL}$ ). However, the indirect system is characterized by slow heating of the product in tubes or plates (lactulose values range of 0.010 to $0.065 \mathrm{~g} / 100 \mathrm{~mL}$ ) [37]. Although the UHT system was not showed in any label, the levels of lactulose were within the limit values and suggested that there was not an additional heating to UHT process. Our results are according to Morales et al. [8], Elliott et al. [38], Feinberg et al. [39], and Sakkas et al. [40] who found values of lactulose between 0.012 and $0.046 \mathrm{~g} / 100 \mathrm{~mL}, 0.013$ and $0.024 \mathrm{~g} / 100 \mathrm{~mL}, 0.014$ and $0.040 \mathrm{~g} / 100 \mathrm{~mL}, 0.082 \mathrm{~g} / 100 \mathrm{~mL}$, respectively. 


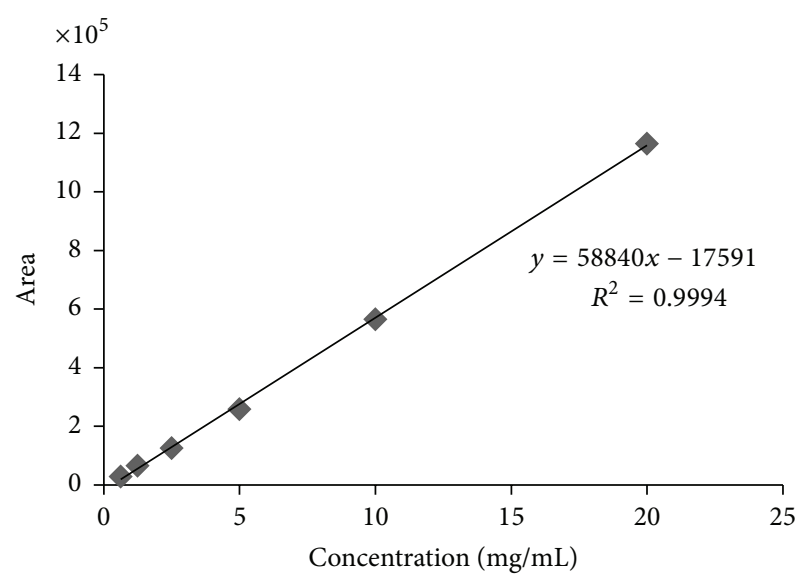

(a)

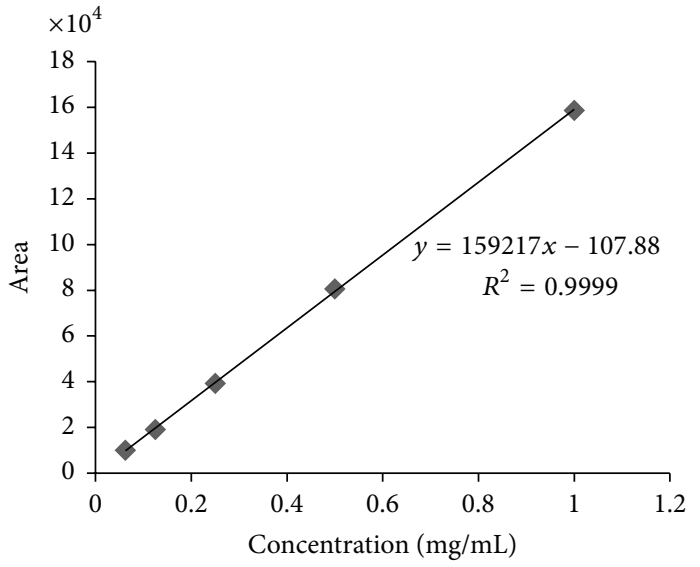

(b)

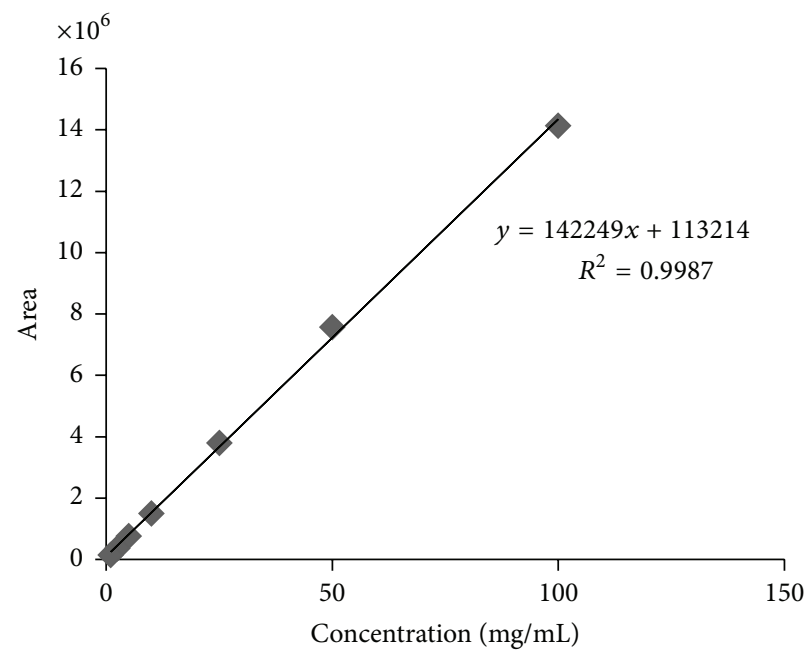

(c)

FIGURE 2: (a) Linearity of lactose by HPLC-RID for both samples. (b) Linearity of lactulose by HPLC-RID for UHT milk samples. (c) Linearity of lactulose by HPLC-RID for condensed milk.

Table 2 shows the values of lactulose and lactose in sweetened condensed milk samples. Lactulose levels ranging from 43.56 to $48.97 \mathrm{~g} / 100 \mathrm{~mL}$ were similar in all brands $(P>0.05)$. These values were higher in contrast to UHT milk; this finding was expected because in the condensed process $60 \%$ of water is removed from the milk and all solid components increase including lactulose. However, lactose levels showed values between 9.96 and $13.86 \mathrm{~g} / 100 \mathrm{~mL}$. These values are similar to those reported by Muehlhoff et al. [2] who found lactose values between 10 and $14 \mathrm{~g} / 100 \mathrm{~mL}$ in different sweetened condensed milks. However, these values were lowest compared with the range from 38 to $45 \mathrm{~g}$ lactose per $100 \mathrm{~g}$ water reported by Walstra et al. [41]. Our results showed slight variations in lactose values in all brands since sweetened condensed milk is elaborated following different methods and the process did not applied high temperature compared with the UHT milk. The determination of lactulose and lactose values in this milk product is not an important indicator for heat treatment.
TABLE 2: Concentrations of lactose and lactulose found in five different commercial brands of condensed milk.

\begin{tabular}{lcc}
\hline \multirow{2}{*}{ Brand codification } & \multicolumn{2}{c}{$\begin{array}{c}\text { Concentration in condensed milk }(\mathrm{g} / 100 \mathrm{~mL}) \\
\text { Lactose }\end{array}$} \\
\hline $\mathrm{COND}_{1}$ & $13.86 \pm 1.15^{\mathrm{a}}$ & $43.56 \pm 3.28^{\mathrm{a}}$ \\
$\mathrm{COND}_{2}$ & $10.63 \pm 0.22^{\mathrm{b}}$ & $44.31 \pm 1.75^{\mathrm{a}}$ \\
$\mathrm{COND}_{3}$ & $9.96 \pm 0.01^{\mathrm{b}}$ & $48.97 \pm 1.22^{\mathrm{a}}$ \\
$\mathrm{COND}_{4}$ & $13.60 \pm 0.56^{\mathrm{a}}$ & $44.62 \pm 1.18^{\mathrm{a}}$ \\
$\mathrm{COND}_{5}$ & $12.36 \pm 0.03^{\mathrm{a}, \mathrm{b}}$ & $43.72 \pm 0.02^{\mathrm{a}}$ \\
\hline
\end{tabular}

$\mathrm{COND}_{n}$ : condensed milk brand.

Values with the same letter in the column indicate that there is no statistically significant difference between the samples to the level of $5 \%$.

Values represent the mean \pm SEM.

Although the heat treatment in UHT milk interferes with the levels of lactose and lactulose, other chemical indicators such as furosine, 5-hydroxymethylfurfural, galactosyl- $\beta$ pyranona, and lysinoalanine can be used to evaluate changes 


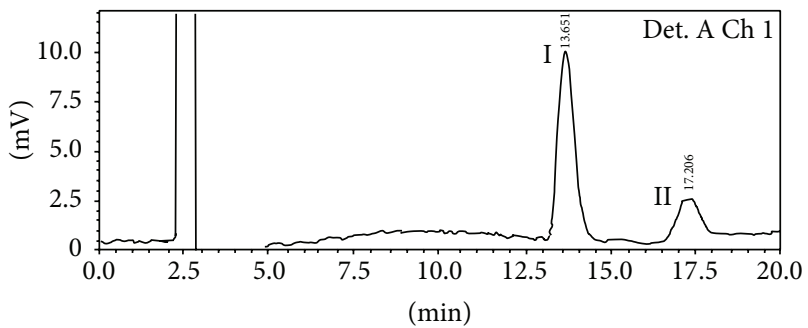

(a)

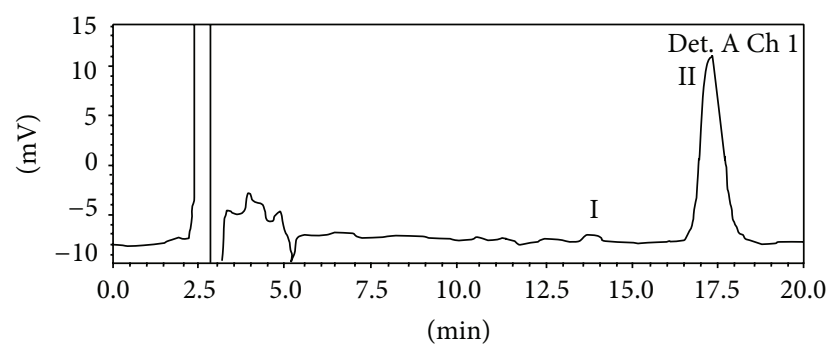

(b)

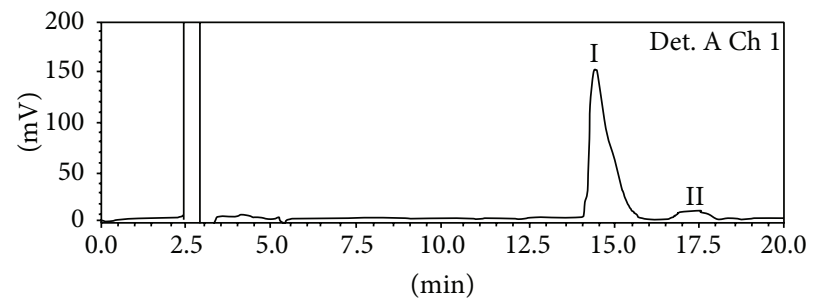

(c)

FIGURE 3: Chromatogram by HPLC-RID: (a) standard lactose-lactulose; (b) UHT milk sample; (c) condensed milk sample. I: lactulose (13.6 min); II: lactose (17.2 min).

in the milk submitted to heat processing [38]. From both, lactulose is a better indicator for heat process but it does not represent itself as a distinguishing criterion. In fact, the combination of different indicators would be a better characterization [42].

\section{Conclusion}

The modified HPLC-RID method is useful in the detection and quantification of lactulose and lactose in dairy products simultaneously. Values of lactose were normal in both milk products. Although UHT milk included high thermal processing, lactulose values remained within the limit values. On the other hand, values of lactulose were high in sweetened condensed milk but this is not an important indicator because the process does not use high temperature. Lactulose is an important indicator of heat treatment; however, the correlation with other substances formed in the milk products after the heat process to define their application in the dairy industry is suggested.

\section{Conflict of Interests}

The authors declare that there is no conflict of interests regarding the publication of this paper.

\section{Acknowledgments}

The authors thank the Fundação de Amparo à Pesquisa do Estado do Rio de Janeiro (Grant no. E-26/103.003/2012, FAPERJ, Brasil) and the Conselho Nacional de Desenvolvimento Científico e Tecnológico (Grant nos. 311361/20137, 313917/2013-2, and 401922/2013-8, CNPq, Brasil) for the financial support.

\section{References}

[1] MAPA, "Instrução Normativa n. 51: Anexo I-Regulamento Técnico de Produção, Identidade e Qualidade de Leite Tipo A," in Abastecimento MdAAd, MAPA, Brasília, Brazil, 2002.

[2] E. Muehlhoff, A. Bennett, and D. McMahon, "Introduction," in Milk and Dairy Products in Human Nutrition, E. Muehlhoff, A. Bennett, and D. McMahon, Eds., pp. 1-10, FAO, Rome, Itlay, 2013.

[3] FAO, Food and Agricultural Commodities Production: Top Production-Cow Milk, Whole, Fresh, FAO, Rome, Italy, 2011, http://faostat.fao.org/site/339/default.aspx.

[4] Produção da Pecuária Municipal, Comentários, 2010.

[5] L. Mortier, A. Braekman, D. Cartuyvels, R. van Renterghem, and J. de Block, "Intrinsic indicators for monitoring heat damage of consumption milk," Biotechnology, Agronomy and Society and Environment, vol. 4, no. 4, pp. 221-225, 2000.

[6] N. Y. Farkye, "Evaporated and sweetened condensed milks," in Dairy Processing \& Quality Assurance, chapter 13, pp. 309-318, Wiley-Blackwell, 2009.

[7] S. D. S. Castro, Avaliação experimental e modelagem da elevação do ponto de ebulição do leite adicionado de sacarose [Ph.D. thesis], Universidade Federal de Viçosa, Minas Gerais, Brazil, 2006.

[8] F.-J. Morales, C. Romero, and S. Jiménez-Pérez, "Characterization of industrial processed milk by analysis of heat-induced changes," International Journal of Food Science \& Technology, vol. 35, no. 2, pp. 193-200, 2000.

[9] M. R. Mendoza, A. Olano, and M. Villamiel, "Chemical indicators of heat treatment in fortified and special milks," Journal of Agricultural and Food Chemistry, vol. 53, no. 8, pp. 2995-2999, 2005.

[10] R. López-Fandiño and A. Olano, "Review: selected indicators of the quality of thermal processed milk/Revisión: indicadores seleccionados para el control de calidad de la leche tratada termicamente," Food Science and Technology International, vol. 5, no. 2, pp. 121-137, 1999. 
[11] K. Kailasapathy, "Chemical composition, physical and functional properties of milk and milk ingredients," in Dairy Processing \& Quality Assurance, chapter 4, pp. 75-103, WileyBlackwell, 2009.

[12] W. L. Claeys, L. R. Ludikhuyze, and M. E. Hendrickx, "Formation kinetics of hydroxymethylfurfural, lactulose and furosine in milk heated under isothermal and non-isothermal conditions," Journal of Dairy Research, vol. 68, no. 2, pp. 287-301, 2001.

[13] J. Belloque, R. Chicón, and I. Récio, "Quality control," in Milk Processing and Quality Management, A. Y. Tamime, Ed., pp. 1726, Wiley-Blackwell, New Delhi, India, 2009.

[14] J. O’Brien, "Non-enzymatic degradation pathways of lactose and their significance in dairy products," in Advanced Dairy Chemistry, P. McSweeney and P. F. Fox, Eds., pp. 231-294, Springer, New York, NY, USA, 2009.

[15] S. Adachi, "Formation of lactulose and tagatose from lactose in strongly heated milk," Nature, vol. 181, no. 4612, pp. 840-841, 1958.

[16] J. A. Ordoñez, Tecnología de los Alimentos: Alimentos de Origen Animal, Síntesis, 2005.

[17] R. Schuster-Wolff-Bühring, R. Michel, and J. Hinrichs, "A new liquid chromatography method for the simultaneous and sensitive quantification of lactose and lactulose in milk," Dairy Science \& Technology, vol. 91, no. 1, pp. 27-37, 2011.

[18] N. Corzo, A. Olano, and I. Martínez-Castro, "Carbohyrates," in Handbook of Dairy Foods Analysis, L. M. L. Nollet and F. Toldra, Eds., pp. 139-167, Taylor \& Francis, Boca Raton, Fla, USA, 2009.

[19] C. M. Andersen and G. Mortensen, "Fluorescence spectroscopy: a rapid tool for analyzing dairy products," Journal of Agricultural and Food Chemistry, vol. 56, no. 3, pp. 720-729, 2008.

[20] A. Olano, M. M. Calvo, and N. Corzo, "Changes in the carbohydrate fraction of milk during heating processes," Food Chemistry, vol. 31, no. 4, pp. 259-265, 1989.

[21] A. Montilla, F. J. Moreno, and A. Olano, "A reliable gas capillary chromatographic determination of lactulose in dairy samples," Chromatographia, vol. 62, no. 5-6, pp. 311-314, 2005.

[22] A. Amine, D. Moscone, R. A. Bernardo, E. Marconi, and G. Palleschi, "A new enzymatic spectrophotometric assay for the determination of lactulose in milk," Analytica Chimica Acta, vol. 406, no. 2, pp. 217-224, 2000.

[23] E. Marconi, M. C. Messia, A. Amine et al., "Heat-treated milk differentiation by a sensitive lactulose assay," Food Chemistry, vol. 84, no. 3, pp. 447-450, 2004.

[24] M. Luzzana, D. Agnellini, P. Cremonesi, G. Caramenti, and S. De Vita, "Milk lactose and lactulose determination by the differential pH technique," Lait, vol. 83, no. 5, pp. 409-416, 2003.

[25] X. Zhang, Y. Cao, and J. Ye, "Determination of lactose in sugarfree milk powder by capillary electrophoresis with electrochemical detection," Food Chemistry, vol. 72, no. 3, pp. 385-388, 2001.

[26] Z. Zhang, R. Yang, H. Wang, F. Ye, S. Zhang, and X. Hua, "Determination of lactulose in foods: a review of recent research," International Journal of Food Science and Technology, vol. 45, no. 6, pp. 1081-1087, 2010.

[27] D. L. Sexton, Determination of lactose by reversed-phase high performance liquid chromatography [M.S. thesis], East Tennessee State University, Johnson City, Tenn, USA, 2004.

[28] J. L. Chávez-Servín, A. I. Castellote, and M. C. López-Sabater, "Analysis of mono- and disaccharides in milk-based formulae by high-performance liquid chromatography with refractive index detection," Journal of Chromatography A, vol. 1043, no. 2, pp. 211-215, 2004.
[29] GraphPad, GraphPad Prisma Version 5.0, GraphPad Software, San Diego, Calif, USA, 2007.

[30] J. A. Paschoal, S. Rath, F. P. Airoldi, and F. G. Reyes, "Validação de métodos cromatográficos para a determinação de resíduos de medicamentos veterinários em alimentos," Química Nova, vol. 31, no. 5, pp. 1190-1198, 2008.

[31] INMETRO, Orientações sobre Validação de Métodos Analiticos, DOQ-CGCRE-008, Instituto Nacional de Metrologia, Normalização e Qualidade Industrial, Rio de Janeiro, Brazil, 2011.

[32] ANVISA, Agência Nacional de Vigilância Sanitária-RE $N^{\circ}$ 899. Guia para Validação de Métodos Analíticos e Bioanalíticos, Diário Oficial da União, Brasília, Brazil, 2003.

[33] V. P. Shah, K. K. Midha, J. W. A. Findlay et al., "Bioanalytical method validation - a revisit with a decade of progress," Pharmaceutical Research, vol. 17, no. 12, pp. 1551-1557, 2000.

[34] P. Walstra, J. T. M. Wouters, and T. J. Geurts, "Heat treatment," in Dairy Science and Technology, P. Walstra, J. T. M. Wouters, and T. J. Geurts, Eds., Food Science and Technology, pp. 225-272, CRC Press, Boca Raton, Fla, USA, 2nd edition, 2005.

[35] L. Pellegrino, I. De Noni, and P. Resmini, "Coupling of lactulose and furosine indices for quality evaluation of sterilized milk," International Dairy Journal, vol. 5, no. 7, pp. 647-659, 1995.

[36] G. Smit, Dairy Processing: Improving Quality, Elsevier Science, 2003.

[37] M. J. Lewis and H. C. Deeth, "Heat treatment of milk," in Milk Processing and Quality Management, A. Y. Tamime, Ed., pp. 168204, Wiley-Blackwell, New Delhi, India, 2009.

[38] A. J. Elliott, N. Datta, B. Amenu, and H. C. Deeth, "Heatinduced and other chemical changes in commercial UHT milks," Journal of Dairy Research, vol. 72, no. 4, pp. 442-446, 2005.

[39] M. Feinberg, D. Dupont, T. Efstathiou, V. Louâpre, and J.P. Guyonnet, "Evaluation of tracers for the authentication of thermal treatments of milks," Food Chemistry, vol. 98, no. 1, pp. 188-194, 2006.

[40] L. Sakkas, A. Moutafi, E. Moschopoulou, and G. Moatsou, "Assessment of heat treatment of various types of milk," Food Chemistry, vol. 159, pp. 293-301, 2014.

[41] P. Walstra, J. T. M. Wouters, and T. J. Geurts, "Concentrated milks," in Dairy Science and Technology, P. Walstra, J. T. M. Wouters, and T. J. Geurts, Eds., Food Science and Technology, pp. 497-512, CRC Press, Boca Raton, Fla, USA, 2nd edition, 2005.

[42] S. Cattaneo, F. Masotti, and L. Pellegrino, "Effects of overprocessing on heat damage of UHT milk," European Food Research and Technology, vol. 226, no. 5, pp. 1099-1106, 2008. 

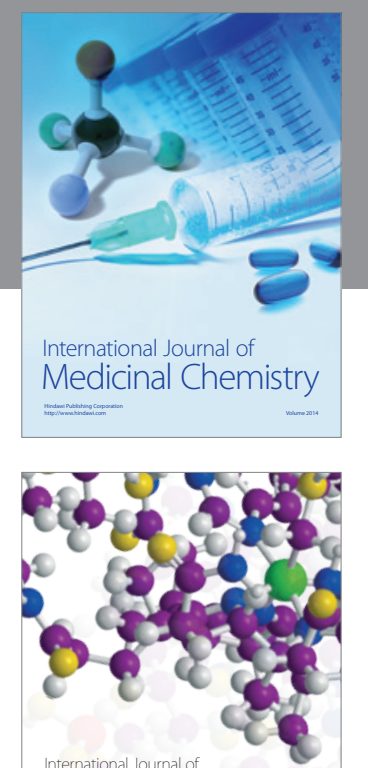

\section{Carbohydrate} Chemistry

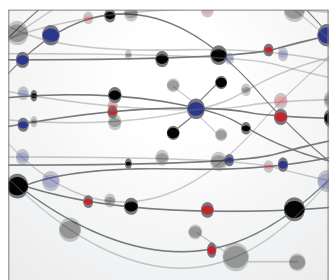

The Scientific World Journal
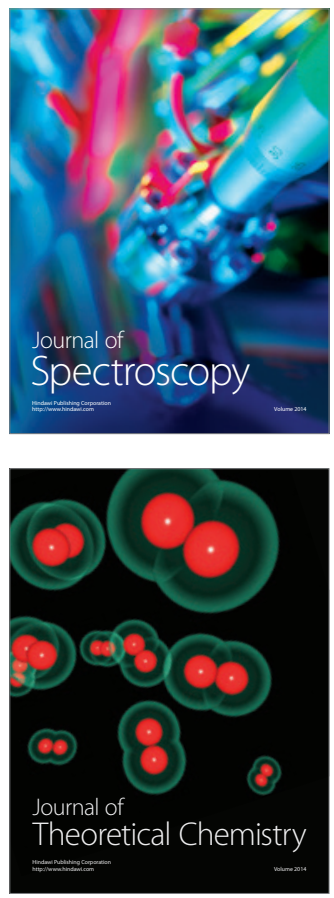
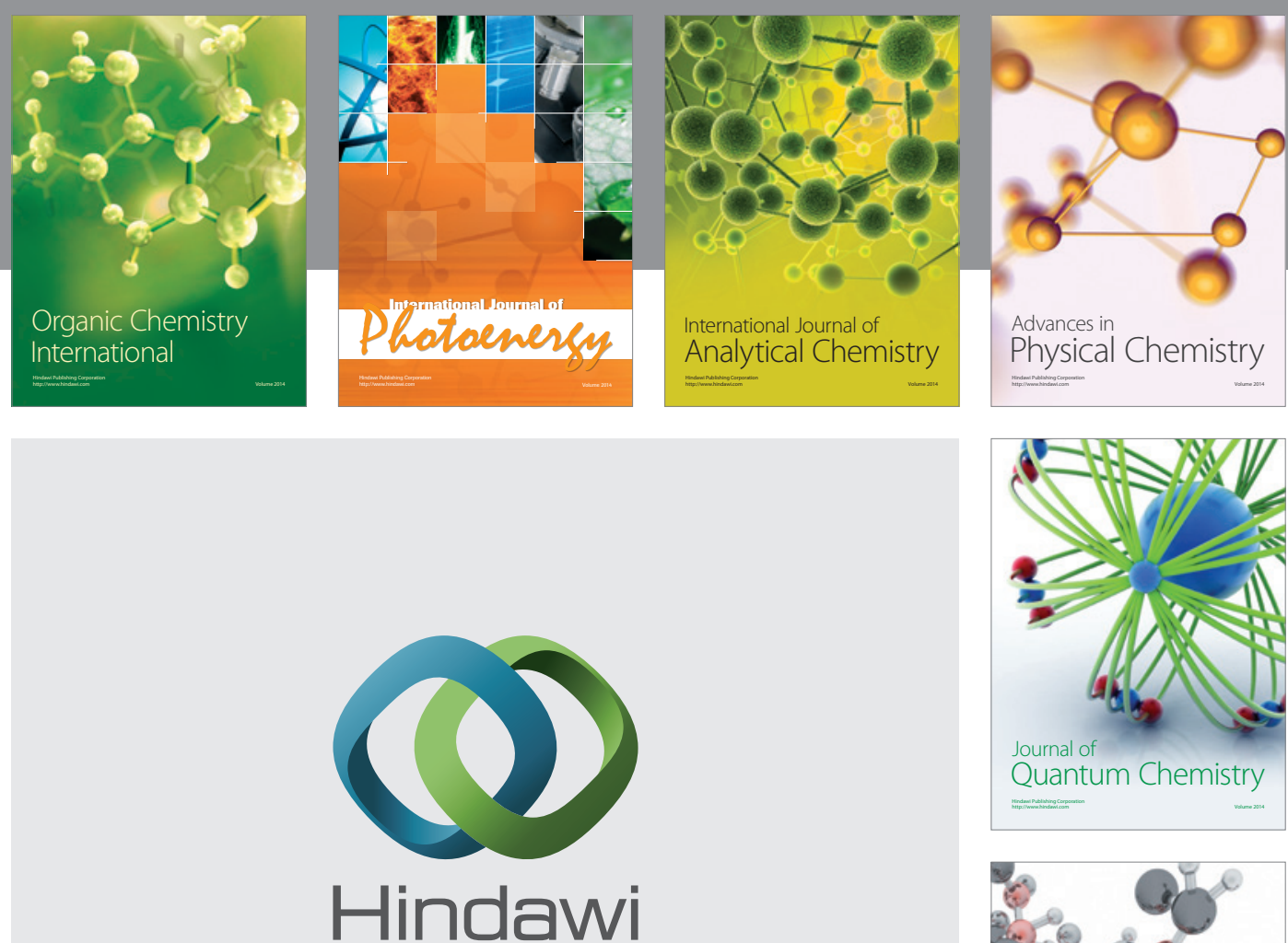

Submit your manuscripts at

http://www.hindawi.com

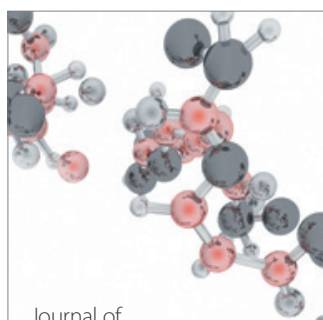

Analytical Methods

in Chemistry

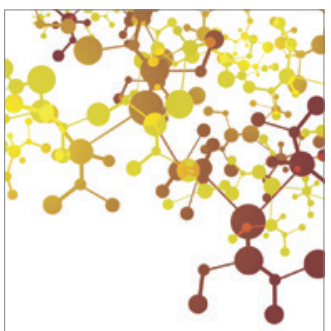

Journal of

Applied Chemistry

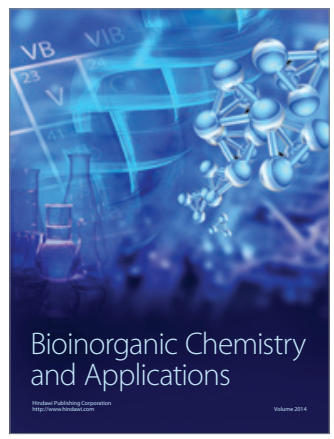

Inorganic Chemistry
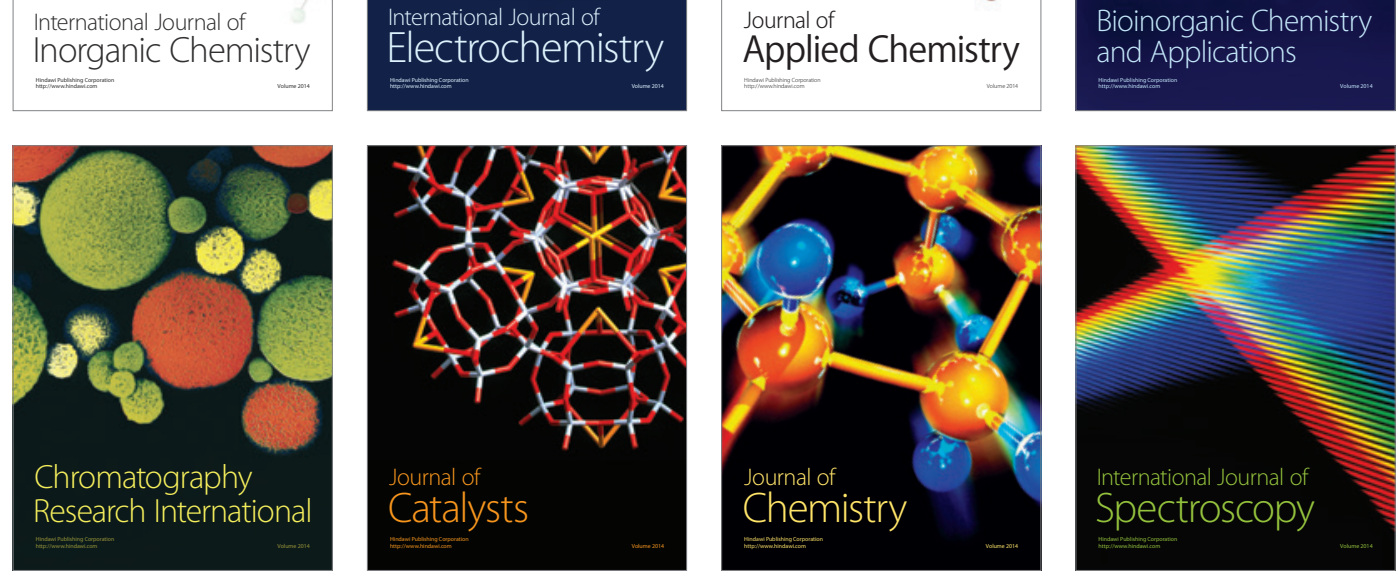